\title{
KEADILAN EKONOMI DALAM PRESPEKTIF HUKUM ISLAM
}

\author{
Wing Redy Prayuda \\ Fakultas Syari'ah dan Ekonomi Islam \\ Institut Agama Islam Negeri Syekh Nurjati Cirebon \\ email: redyprayuda@gmail.com
}

\begin{abstract}
Humans, as social beings, cannot stand-alone so that they need to interact with others to carry out daily economic activities. In human lifespan, a man wants justice in all things, including the economy however the soul of the human soul tends to follow the passions that allow humans to put more injustice than justice or the truth. Materialism has separated the human from economy and ethics. The capitalist system makes human beings concerned with the protection of individual rights and ignores the common interests of society, as the communist system disrupts one's rights. Meanwhile Islamic Economics puts a balance between religion and state, religion and science, the material with spiritual. In addition, the rights and duties provide the freedom that is controlled by not damaging the common interest and bound by the signs of Syariah. Islamic economics present brings the new atmospheres to the world economy.
\end{abstract}

Kata Kunci: Islamic economics, Justice.

\begin{abstract}
Abstrak
Manusia sebagai makhluk sosial tidak dapat berdiri sendiri sehingga perlu interaksi dengan yang lain, demikian dalam menjalankan aktivitas ekonomi sehari-hari. Dalam menjalankan roda kehidupan, manusia menghendaki keadilan dalam segala hal, termasuk perekonomian, numun jiwa manusia cenderung mengikuti hawa nafsu yang memungkinkan manusia lebih mendahulukan kezaliman dari pada keadilan dan kabatilan dari pada kebenaran. Materialisme telah memisahkan manusia dari ekonomi dan etika. Sistem kapitalis menjadikan manusia mementingkan perlindungan atas hak perseorangan dan mengabaikan kepentingan bersama dari masyarakat, demikian sistem komunistis menghancurleburkan hak-hak seseorang. Sedangkan Ekonomi Islam meletakkan keseimbangan antara agama dan negara, agama dan keilmuan, materi dengan spriritual, hak dan kewajiban serta bemberikan kebebasan yang terkendali dengan tidak merusak kepentingan bersama dan terikat dengan rambu-rambu syariah. Ekonomi Islam hadir membawa warna kesejukan bagi perekonomian dunia.
\end{abstract}

Keywords: Ekonomi Islam, Keadilan. 


\section{PENDAHULUAN}

Pada umumnya manusia menghendaki kesejahteraan dalam hidupnya. Baik kesejahteraan individu, kelompok, atau bahkan yang lebih besar. Masalah ekonomi selalu menarik perhatian individu dan masyarakat. Dalam pemenuhan kebutuhan ekonomi berbagai usaha dilakukan dan berbagai cara difungsikan untuk mengatasi atau memecahkan masalah ini. Sebagian usaha mereka berhasil hingga mencapai puncaknya, sebagian lagi kehilangan arah dan keseimbangan.

Roda kehidupan selalu berputar, aktivitas ekonomi yang dilangsungkan oleh manusia memungkinkan terjadinya ketimpangan atau ketidakseimbangan. Hakhak seseorang bisa saja terkekang, kepentingan bersamapun menjadi terabaikan, sebagaimana terjadi dalam sistem ekonomi kapitalis dan ekonomi sosialis. Sedangkan Islam menghormati hakhak individu dan masyarakat dan lebih mengarah kepada kepentingan bersama. Di samping didasarkan pada komitmen spiritual, Islam juga didasarkan atas konsep persaudaraan universal.

Yang membedakan Islam dengan materialisme ialah bahwa Islam tidak pernah memisahkan ekonomi dan etika, sebagaimana tidak memisahkan ilmu dan akhlak, politik dan etika, perang dan etika, dan kerabat sedarah sedaging dengan kehidupan Islam. hal ini sesuai dengan misi diutusnya Rasulallah Saw. untuk menyempurnakan akhlak manusia. Islam tidak memisahkan agama dengan negara dan materi dengan spiritual sebagaimana dilakukan bangsa Eropa dengan konsepsekularismenya. Islam juga berbeda dengan konsep kapitalisme yang memisahkan akhlak dengan ekonomi, manusia muslim, individu maupun kelompok, dalam lapangan ekonomi atau bisnis, di satu sisi diberi kebebasan untuk mencari keuntungan sebesar-besarnya. Namun di sisi lain, ia terikat dengan iman dan etika, sehingga ia tidak bebas mutlak dalam menginvestasikan modalnya atau membelanjakan hartanya.
Masyarakat muslim tidak bebas tanpa kendali dalam memproduksi segala sumber daya alam, mendistribusikannya, atau mengkonsumsinya. Ia terikat dengan ramburambu syariah. Misalnya larangan berternak babi, menujual atau mengkonsumsi minuman keras, larangan jual beli ketika datangnya shalat jum'at, bisnis prostitusi, dan lain-lainnya. Karena itu para pakar ekonomi non muslim mengakui keunggulan sistem ekonomi Islam. Islam telah sukses menggabungkan etika dan ekonomi, sementara sistem kapitalis dan sosialis memisahkan keduanya. ${ }^{1}$

Dari uraian di atas, tulisan ini hendak menjawab 2 (dua) permasalahan besar yang sudah seyogyanya menjadi laku hidup dalam sistem ekonomi di Indonesia, yaitu pertama, bagaimana bangunan keadilan ekonomi yang diterapkan dalam hukum Islam? Dan kedua, apa manfaat dalam menerapkan sistem ekonomi Islam dalam kehidupan saat ini?

\section{KEADILAN EKONOMI \\ Konsep Dasar Ekonomi dan Ekonomi Islam}

Istilah 'ekonomi' berasal dari bahasa Yunani, yaitu oikonomia yang artinya manajemen urusan rumah tangga, khususnya penyediaan dan administrasi pendapatan. $^{2}$ Istilah ekonomi menunjuk pada prinsip usaha atau metode untuk mencapai tujuan dengan alat-alat sedikit mungkin.

Menurut Albert L. Meyers, ilmu ekonomi adalah ilmu yang mempersoalkan kebutuhan dan pemuasan kebutuhan manusia. Ahli ekonomi lainnya mengemukakan bahwa ilmu ekonomi adalah ilmu tentang usaha manusia ke arah kemakmuran. Kedua definisi di atas tampak terlalu luas sehingga masih sulit dipahami

\footnotetext{
${ }^{1}$ Yusuf Qardhawi, Norma dan Etika Ekonomi Islam, terj. Zainal Arifin (Jakarta: Gema Insani Press, 1995), 55.

${ }^{2}$ Komaruddin Sastradipoera, Sejarah Pemikiran Ekonomi: Suatu Pengantar Teori dan Kebijaksanaan Ekonomi (Bandung: Kappa-Sigma, 2001), 4.
} 
secara spesifik. Sedangkan Samuelson dan Nordhaus mengemukakan, ilmu ekonomi merupakan studi tentang perilaku orang dan masyarakat dalam memilih cara menggunakan sumber daya yang langka serta memiliki beberapa alternatif penggunaan, dalam rangka memproduksi berbagai komoditas, untuk kemudian menyalurkannya - baik saat ini maupun masa depan - kepada berbagai individu dan kelompok yang ada dalam suatu masyarakat. $^{3}$

Melihat definisi-definisi di atas, pada hakikatnya ilmu ekonomi merupakan usaha manusia untuk memenuhi kebutuhannya dalam mencapai kemakmuran yang diharapakan. Sederhananya, ilmu ekonomi merupakan disiplin tentang aspek-aspek ekonomi dan tingkah laku manusia. Secara fundamental dan historis, ilmu ekonomi dapat dibedakan menjadi dua, yaitu ilmu ekonomi positif dan normatif. Ilmu ekonomi positif hanya membahas deskripsi mengenai fakta, situasi, dan hubungan yang terjadi dalam ekonomi. Ilmu ekonomi normatif membahas pertimbangan nilai dan etika, seperti sistem perpajakan harus diarahkan pada kaidah mengambil dari yang kaya untuk menolong yang miskin atau tidak. ${ }^{4}$

Berdasarkan ruang lingkupnya, ilmu ekonomi juga dapat dibedakan atas makroekonomi dan mikroekonomi. Ekonomi makro merupakan cabang ilmu ekonomi yang khusus mempelajari mekanisme cara bekerja perekonomian, sebagai suatu keseluruhan (agregat) berkaitan dengan penggunaan faktor produksi yang tersedia secara efisien, agar kemakmuran masyarakat dapat dimaksimumkan. Sedangkan ekonomi mikro merupakan cabang ilmu ekonomi yang khusus mempelajari bagian-bagian kecil (aspek individul) dari keseluruhan kegiatan perekonomian. Analisis dalam teori

\footnotetext{
${ }^{3}$ Paul A. Samuelson dan William D. Nordhaus, Ekonomi, Jilid 1, terj. Jaka Wasana (Jakarta: Erlangga, 1990), 5.

${ }^{4}$ Lihat Siti Nur Fatoni, Pengantar Ilmu Ekonomi (Bandung: Pustaka Setia, 2014), 18-19.
}

ekonomi mikro antara lain meliputi perilaku pembeli (konsumen) dan produsen secara individual dalam pasar. Sikap dan perilaku konsumen tercermin dalam upaya penggunaan pendapatan yang diperolehnya, sedangkan sikap dan perilaku produsen tercermin dalam caranya menawarkan barang. Inti dalam ekonomi mikro adalah masalah penentuan harga. Itulah sebabnya, ekonomi mikro sering dinamakan dengan teori harga (price theory). ${ }^{5}$

Istilah ekonomi dalam Islam dikenal dengan istilah iqtishadiyah. Istilah ekonomi tidak banyak dijumpai dalam Al-Qur'an. Akan tetapi, dengan terminologi bisnis, istilah ini sangat beragam, sebagaimana dijumpai dalam Surat al-Baqarah (2) ayat 282 yang mengandung banyak petunjuk tentang masalah hukum ekonomi.

Menurut M. Quraisy Shihab ${ }^{6}$ bahwa dalam Al-Qur'an banyak ditemukan ungkapan tentang ekonomi dan bisnis. Misalnya, ketika mengajak untuk beramal, Al-Qur'an sering menggunakan istilahistilah yang dikenal dan berhubungan erat dengan bidang ekonomi dan bisnis. Demikian pula istilah-istilah seperti bisnis, jual beli, perbendaharaan, harta benda, utang piutang, permodalan, usaha dan kerja, rezeki, keuntungan, upah, dan lain-lain. AlQur'an menawarkan keuntungan yang tidak mengenal kerugian dan penipuan, ${ }^{7}$ ada janji keuntungan bisnis yang tidak pernah rugi, ${ }^{8}$ keuntungan sebagai akibat dari karya usaha yang baik, dalam Al-Quran dijanjikan Allah Swt. dengan tujuh ratus kali lipat keuntungan, ${ }^{9}$ ekonomi dan bisnis harus dilakukan setelah melakukan shalat. ${ }^{10}$ Demikian pula, berbisnis harus dilakukan dengan cara saling menguntungkan, baik pada waktu dilakukan maupun setelahnya. ${ }^{11}$

${ }^{5}$ Siti Nur Fatoni, Pengantar Ilmu Ekonomi, 23.

${ }^{6}$ M. Quraisy Shihab, Wawasan Al-Qur'an (Bandung: Mizan, 1996), 302.

${ }^{7}$ QS. Al-Taubah (9): 111.

${ }^{8}$ QS Al-Fathir (35): 29.

${ }^{9}$ QS. Al-Baqarah (2): 261.

${ }^{10}$ QS. Al-Jumu'ah (62): 9.

${ }^{11}$ QS. Al-Nisa (4): 29. 
Berdasarkan sudut pandang terminologis tentang bisnis, Al-Qur'an memiliki istilah-istilah, di antaranya: altijārah, al-bai'u, tadāyantum, dan isytara. Dalam penggunaan istilah tijārah terdapat dua macam pemahaman. Pertama, dipahami dengan perdagangan. ${ }^{12}$ Kedua, dipahami dengan perniagaan dalam pengertian umum. Dihubungkan dengan konteksnya masingmasing, pengertian perniagaan pada ayat tersebut tidak hanya berhubungan dengan hal-hal yang bersifat materiel (kuantitas), tetapi lebih tertuju pada hal yang bersifat immateriel (kualitatif). Makna perniagaan dalam konteks materiel misalnya, disebutkan dalam Al-Qur'an suarat AlTaubah (9): 24, Al-Nur (24): 37, dan AlJumu'ah (62): 11. Adapun perniagaan dalam konteks materiel sekaligus immateriel terlihat pada pemahaman tijarah dalam beberapa ayat Al-Qur'an, seperti surat AlFathir (35): 29 dan Al-Shaff (61): 10-11.

Paparan di atas pada dasarnya menegaskan tiga hal. Pertama, Al-Qur'an memberikan tuntunan bisnis yang jelas, yaitu visi bisnis masa depan yang tidak hanya mencari keuntungan sesaatm tetapi mencari keuntungan yang hakiki yang baik dan berakibat baik pula setelahnya. Kedua, keuntungan bisnis menurut Al-Qur'an tidak hanya bersifat materiel, tetapi bersifat materiel sekaligus immateriel, bahkan lebih mengutamakan hal yang bersifat immateriel (kualitas).

Dan Ketiga, bisnis tidak hanya berhubungan dengan manusia, tetapi juga berhubungan dengan Allah Swt. Dengan demikian, terkait bisnis, dalam Al-Qur'an sudah terdapat implementasi etika bisnis. Kekuatan doktrin ajaran Al-Qur'an tentang ekonomi dan bisnis terlukis jelas dalam suri tauladan kehidupan Nabi Muhammad Saw., baik sebelum kenabian maupun setelah kenabian. Profesi utama yang dijalankan Nabi Muhammad Saw. adalah menjadi seorang bussinessmen yang sukses. ${ }^{13}$

\footnotetext{
${ }^{12}$ QS. Al-Baqarah (2): 282.

13 Nur Fatoni, Pengantar Ilmu Ekonomi, 153155.
}

Pada perkembangannya, istilah ekonomi dalam Islam sering kita jumpai dengan sebutan "ekonomi Islam" atau "ekonomi syariah", demikian juga para pakar ekonomi Islam dalam menggunakan istilah keduanya, yang mana pada dasarnya adalah tidak jauh berbeda. M. N Siddiqi yang memberikan definisi, Islamic economics is 'the moslem thinker' response to the economic challenges of their times. In this endeavor they were aided by the Qur'an and the Sunnah as well as by reason and experience. ${ }^{14}$ Ilmu ekonomi Islam adalah respon 'para pemikir muslim' terhadap tantangan-tantangan ekonomi zaman mereka. Dalam upaya ini, mereka dibantu oleh Al-Qur'an dan Al-Sunnah ataupun akal dan pengalaman.

S. M Hasanuz Zaman memberikan definisi Islamic Economics is the knowledge and applications and rules of the shariah that prevent injustice in the requisition and disposal of material resources in order to provide satisfaction to human being and anable them to perform the obligations to Allah and the society. ${ }^{15}$ Ilmu ekonomi Islam adalah pengetahuan dan aplikasi ajaranajaran dan aturan-aturan syariah yang mencegah ketidakadilan dalam pencarian dan pengeluaran sumber-sumber daya, untuk memberi kepuasan bagi manusia dan memungkinkan mereka melaksanakan kewajiban-kewajiban mereka terhadap Allah dan masyarakat.

Muhammad Abdul Manan berpendapat bahwa, ilmu ekonomi syariah adalah ilmu pengetahuan sosial yang mempelajari masalah-masalah ekonomi masyarakat yang diilhami oleh nilai-nilai Islam. Ia mengatakan bahwa ekonomi Islam merupakan bagian dari tata kehidupan lengkap, berdasarkan empat bagian nyata

${ }^{14}$ Mohammad Nejatullah Siddiqi, Role of the State in the Economy: An Islamic Perspective (UK: The Islamic Foundation, 1992), 112.

${ }^{15}$ S. M. Hasanuz Zaman, Economic Functions of an Islamic State (London: The Islamic Foundation, 1991), 87. 
dari pengetahuan, yaitu Al-Qur'an, AsSunnah, Ijma, dan Qiyas. ${ }^{16}$.

Menurut Muhammad Abdullah Al'Arabi, ekonomi syariah merupakan sekumpulan dasar-dasar umum ekonomi yang kita simpulkan dari Al-Qur'an dan AlSunnah, dan merupakan bangunan perekonomian yang kita dirikan di atas landasan dasar-dasar tersebut sesuai tiap lingkungan dan masa. ${ }^{17}$ Syed Nawab Haider Naqvi memberikan definisi, Islamic Economics is the representative Moslem's behaviour in a typycal moslem society, yang berarti ekonomi Islam adalah perilaku (ekonomi) umat Islam pada masyarakat muslim yang khas. ${ }^{18}$ Sedangkan Zainuddin Ali memberikan definisi, ekonomi syariah adalah kumpulan norma hukum yang bersumber dari Al-Qur'an dan Al-Sunnah yang mengatur perekonomian umat manusia. ${ }^{19}$

\section{Keadilan Ekonomi Perspektif Hukum Islam}

Al-Qur'an mengingatkan dalam berbagai ayat bahwa jiwa manusia cenderung mengikuti hawa nafsu. Kecintaan dan kebencian merupakan faktor yang memungkinkan manusia mendahulukan kebatilan dari pada kebenaran, mendahulukan kezaliman dari pada keadilan. Dalam surat Al-Maidah (5) ayat 8 dinyatakan, hai orang-orang yang beriman, hendaklah kamu jadi orang-orang yang selalu menegakkan kebenaran karena Allah, menjadi saksi dengan adil. Dan janganlah kebencianmu terhadap sesuatu kaum

\footnotetext{
${ }^{16}$ M. Abdul Mannan, Ekonomi Syariah: Dari Teori ke Praktek, terj. Potan Arif Harahap (Jakarta: PT. Intermasa, 1992), 19.

${ }^{17}$ Ahmad Muhammad al-'Assal dan Fathi Ahmad Abdul Karim, Sistem Ekonomi Islam: Prinsip-prinsip dan Tujuan-tujuannya (Surabaya: PT. Bina Ilmu, 1980), 11.

${ }^{18}$ Syed Nawab Heider Naqvi, Islam, Economics, and Society, (London and New York: Kegan Paul International, 1994), 65.

${ }^{19}$ Zainuddin Ali, Hukum Ekonomi Syariah (Jakarta: Sinar Grafika, 2008), 4. Lihat juga Mardani, Hukum Ekonomi Syariah di Indonesia (Bandung: PT. Refika Aditama, 2011), 1.
}

mendorong kamu untuk berbuat tidak adil. Berlakulah adil, karena adil itu lebih dekat kepada taqwa. Dan bertakwalah kepada Allah, sesungguhnya Allah Maha mengetagui apa yang kamu kerjakan. ${ }^{20}$

Allah memerintahkan manusia untuk berlaku adil dalam segala hal. Perintah berlaku adil ditujukkan kepada setiap orang, tanpa pandang bulu. Keharusan berlaku adil itu terutama ditujukkan kepada mereka yang mempunyai kekuasaan, atau yang mempunyai hubungan kekuasaan. Keharusan berlaku adil pun mesti ditegakkan di dalam keluarga dan masyarakat, bahkan kepada orang kafir sekalipun. Keadilan dalam hukum Islam berarti pula keseimbangan antara kewajiban yang harus dipenuhi oleh manusia dengan kemampuan manusia untuk menunaikan kewajiban itu. $^{21}$

Kata al- 'adl banyak kita jumpai dalam Al-Qur'an di mana pengertiannya senada dengan kata al-mizān dan al-qisth. Kata al'adl dapat diterjemahkan ke dalam bahasa Indonesia dengan adil dan keadilan. Kata $a l$ mizān berarti timbangan, yakni keseimbangan antara batu timbangan dengan benda yang ditimbang. Karenanya keadilan menjadi prinsip umum hukum Islam yang penerapannya dalam hukum tertentu melahirkan asas keadilan atau keseimbangan. $^{22}$

M. Quraisy Shihab mengatakan, paling tidak ada empat makna keadilan, yaitu pertama, 'adl dalam arti sama. Pengertian ini yang paling banyak terdapat dalam Al-Quran. Kata 'adl dengan arti sama (persamaan) pada ayat-ayat tersebut yang dimaksud adalah persamaan dalam hak. Dalam Al-Qur'an dinyatakan, apabila (kamu) menetapkan hukum di antara 
manusia hendaklah kamu menetapkan dengan adil. ${ }^{23}$

Kedua, 'adl dalam arti seimbang, dalam Al-Qur'an dinyatakan, (Allah) yang telah menciptakan kamu lalu menyempurnakan kejadianmu dan menjadikan (susunan tubunh)-mu seimbang. ${ }^{24}$ Ketiga, al'adl dalam arti perhatian terhadap hak individu dan memberikan hak itu kepada setiap pemiliknya. Disebutkan dalam Al-Qur'an bahwa Dan apabila kamu berkata, maka hendaklah kamu berlaku adil kendatipun dia adalah (kerabat $(\mathrm{mu}){ }^{25}$

Dan keempat, 'adl dalam arti yang dinisbatkan kepada Allah. Keadilan Allah pada dasarnya merupakan rahmat dan kebaikan-Nya. Rahmat Alah Swt. tidak tertahan untuk diperoleh sejauh makhluk itu dapat memperolehnya. Allah memiliki hak atas semua yang ada, sedangkan semua yang ada tidak memiliki sesuatu di sisi-Nya. Di dalam pengertian inilah harus dipahami kandungan surat Ali Imran (3): 18 yang menunjukkan Allah Swt. sebagai qaiman bil qisthi (Yang menegakkan keadialn). ${ }^{26}$

Abdul Ghafur Anshori menyebutkan tiga asas pokok dalam filsafat ekonomi syariah, yaitu: pertama, asas yang menjelaskan bahwa dunia dan seluruh isinya, termasuk alam semesta, adalah milik Allah Swt. dan berjalan menurut kehendakNya; kedua, asas yang menjelaskan bahwa Allah Swt. merupakan pencipta semua makhluk hidup yang ada di alam semesta ini. Konsekuensi yang timbul dari hal tersebut adalah bahwa seluruh makhluk hidup tersebut harus tunduk kepada-Nya; dan ketiga, asas yang menjelaskan bahwa iman kepada hari kiamat akan memengaruhi pola pikir dan tingkah laku ekonomi manusia. ${ }^{27}$ Henri Tanjung sebagaimana dikutip Mardani, syarat suatu bangunan agar

\footnotetext{
${ }^{23}$ QS. Al-Nisa (4): 58.

${ }^{24}$ QS. Al-Infithar (82): 7.

${ }^{25}$ QS. Al-‘An'am (6): 152.

${ }^{26}$ QS. Ali Imran (3): 18.

${ }^{27}$ Abdul Ghofur Anshori, Aspek Hukum Reksa Dana Syariah di Indonesia (Bandung: Refika Aditama, 2008), 46.
}

tetap kokoh adalah tiang yang kokoh. Jika bangunan yang kokoh tersebut adalah ekonomi syariah, maka tiang penyangganya, yaitu: siap menerima resiko, tidak melakukan penimbunan, tidak monopoli, pelarangan interest (riba), solidaritas sosial, keadilan distribusi pendapatan, dan kebebasan individu dalam konteks kesejahteraan sosial. $^{28}$ Menurutnya, ini adalah prinsip-prinsip pokok ekonomi Islam.

M. Quraisy Shihab juga menyatakan, Al-Qur'an menegaskan bahwa dalam beraktivitas ekonomi, umat Islam harus memegang empat prinsip pokok sebagaimana dalam kehidupan lainnya, yaitu tauhid, keseimbangan, kehendak bebas, dan tanggung jawab. ${ }^{29}$

Tujuan yang ingin dicapai dalam sistem ekonomi Islam berdasarkan konsep dasar dalam Islam yaitu tauhid dan berdasarkan rujukan kepada Al-Qur'an dan Al-Sunnah. Pertama, memenuhi kebutuhan dasar manusia meliputi pangan, sandang, papan, kesehatan, dan pendidikan untuk setiap lapisan masyarakat. Kedua, memastikan kesetaraan kesempatan untuk semua orang. Ketiga, mencegah terjadinya pemusatan kekayaan dan meminimalkan ketimpangan dana distribusi pendapatan dan kekayaan di masyarakat. Keempat, memastikan kepada setiap orang kebebasan untuk mematuhi nilai-nilai moral. Lima, memastikan stabilitas dan pertumbuhan ekonomi. ${ }^{30}$

Sistem ekonomi Islam merupakan ilmu ekonomi yang dilaksanakan dalam praktik (penerapan ilmu ekonomi) sehariharinya bagi individu, keluarga, kelompok masyarakat atau pemerintah dalam rangka mengorganisasi faktor produksi, distribusi, dan pemanfaatan barang dan jasa yang tunduk dalam peraturan/perundang-

\footnotetext{
${ }^{28}$ Abdul Ghofur Anshori, Aspek Hukum Reksa Dana Syariah di Indonesia, 17-19.

${ }^{29}$ Lihat M. Quraisy Shihab, Wawasan AlQur'an, 409.

${ }^{30}$ M. Nur Rianto al-Arif, Lembaga Keuangan Syariah: Suatu Kajian Teoretis Praktis (Bandung: CV Pustaka Setia, 2012), 17.
} 
undangan Islam (sunnatullah). Sistem ekonomi Islam adalah sistem ekonomi yang mandiri dan terlepas dari sistem ekonomi lainnya. Pernyataan bahwa sistem ekonomi Islam hanyalah akomodasi dari sistem kapital dan sosialis, hal tersebut terbantahkan melalui pendekatan historis dan faktual. Pada kenyataannya, terlepas dari beberapa kesamaan dengan sistem ekonomi lainnya, terdapat sistem ekonomi Islam memiliki karakterstik khusus. Sistem ekonomi Islam merupakan landasan bagi terbentuknya sistem yang berorientasi terhadap kesejahteraan masyarakat.

Sistem ekonomi Islam tidak terlepas dari seluruh ajaran Islam secara integral dan komprehensif. Karena itu, prinsip-prinsip dasar ekonomi Islam mengacu pada saripati ajaran Islam. Kesesuain sistem tersebut dengan fitrah manusia tidak ditinggalkan. Keselarasan inilah yang menghindari terjadinya benturan-benturan dalam implementasinya. Kebebasan berekonomi terkendali menjadi ciri dalam prinsip ekonomi Islam. Kebebasan memiliki unsur produksi dalam menjalankan roda perekonomian merupakan bagian penting yang tidak merugikan kepentingan kolektif.

Kepentingan individu dibuka lebar, tidak adanya batasan pendapatan seseorang mendorongnya untuk aktif berkarya dengan segala potensi yang dimilikinya, kecenderungan manusia untuk terus menerus memenuhi kebutuhan pribadinya yang tak terbatas dikendalikan dengan adanya kewajiban individu terhadap masyarakatnya. Keseimbangan antara kepentingan individu dan kolektif inilah yang menjadi pendorong bagi bergeraknya roda perekonomian tanpa merusak sistem sosial yang ada. ${ }^{31}$

Sisitem ekonomi kapitalis disusun dengan filsafat dasar sekuler di mana Tuhan dikesampingkan sesuai dengan konsep nihilisme. Dalam situasi ini maka sistem ekonomi dan moneter didesain untuk kepentingan pemilik modal. Akibatnya yang

\footnotetext{
178-179.
}

kaya semakin kaya, yang miskin semakin miskin, kemudian berdampak pada munculnya berbagai masalah sosial dan berbagai dampak negatif lainnya. Lebih parah lagi tidak adanya link antara yang satu dengan yang lain termasuk antara dunia dan akhirat. Dalam sisitem ekonomi sosialis terjadi kelesuan yang ditandai dengan tejadinya pengangguran yang berkelanjutan dan meningkatnya kesenjangan masyarakat, sementara kapitalis semakin menumpuk harta kekayaan.

Ekonomi syariah berbebeda dengan konsep, filosofi, dan sistem ekonomi kapitalis. Sistem ekonomi syariah mengakui adanya Tuhan, adanya kehidupan yang kekal setelah dunia, mengutamakan nilainilai moral, tidak semua bebas tapi ada batas-batas tertentu, lebih mementingkan kepentingan sosial bersama. Pola hubungan antar pihak didasarkan pada kerja sama bukan persaingan individu. ${ }^{32}$ Demikian ekonomi sosialis berbeda dengan sistem ekonomi syariah yang meliputi antara lain. Pertama, mengakui hak miliki individu sepanjang tidak merugikan masyarakat. Kedua, individu mempunyai perbedaan yang dapat dikembangkan berdasarkan potensi masing-masing. Ketiga, adanya jaminan sosial dari negara untuk masyarakat terutama dalam pemenuhan kebutuhan pokok manuisa. ${ }^{33}$

Setiap orang dapat menikmati kebebasan sepenuhnya untuk berbuat sesuatu atau mengambil pekerjaan atau memanfaatkan kekayaan dengan cara yang ia sukai sejalan dengan peraturan negerinya. Islam memperbolehkan orang untuk mencari kekayaan sebanyak mungkin melalui ilmu pengetahuannya, keterampilannya, dan kerjanya dengan menggunakan sarana yang tidak bertentangan dengan kepentingan masyarakat dan moral. Islam mengakui

${ }^{32}$ Sofyan Safri Harahap, "Peluang Ekonomi Syariah dalam Otonomi Daerah", Ekonomi Syariah. Vol. 4, No. 8 (Juni, 2006): 45.

${ }^{33}$ Veithzal Rivai dan Andi Buchari, Islamic Economics (Jakarta: Bima aksara, 2009), 34. 
adanya ketidaksamaan dari kemampuan dan daya kekuatan seseorang yang menyebabkan adanya ketidaksamaan perolehan atau hasil berupa materi maupun sosial. Karena masyarakat merupakan satu organisme, Islam melarang usaha yang membawa pada pemusatan kekayaan pada beberapa tangan.

Islam mengakui hak perseorangan untuk memiliki kekayaan, tetapi tunduk pada pembatasan agar kekayaan itu tidak membahayakan terhadap kepentingan bersama dari masyarakat. Islam menetapkan bahwa seseorang memiliki dua kedudukan secara bersamaan, yaitu kedudukan sebagai individu yang bebas mandiri, dan kedudukan sebagai anggota masyarakat. Islam memberikan kebebasan terhadap keinginan alami seseorang atas kepemilikan pribadi, serta berusaha memenuhi kecenderungan alami manusia dengan cara yang paling baik bagi keduanya. Islam mengakui hak perseorangan, tetapi tidak membiarkannya bebas sesuka hati melalui cara yang ia sukai. Islam tidak menghendaki peluasan hak milik pribadi hingga membahayakan landasan sistem Islam karena hal itu akan merusak tujuannya yang benar.

Seseorang dapat menikmati hak-hak tertentu, namun mempunyai kewajiban tertentu kepada masyarakat yang telah memberikan hak itu kepadanya. Seseorang mempunyai hak untuk memiliki harta kekayaan, membeli, menjual atau mewariskan, tetapi disertai dengan tanggung jawab dan kewajiban yang harus dibayar kepada masyarakat. Dengan kata lain, hak perseorangan atas harta kekayaan tidak mutlak, tetapi terbatas dan dibatasi oleh tanggung jawab dan kewajiban yang menyertai hak itu. Karena itu, sistem ekonomi Islam merupakan sistem yang menselaraskan antara maslahat individu dan maslahat umum, bukan memisahkan keduanya, sehingga keadilan pun tercipta.

Pada hakikatnya kekayaan adalah milik Allah Swt., apapun harta yang Allah berikan kepada manusia merupakan amanah dari Allah Swt. Jika terjadi ketidakseimbangan dalam hal harta antar sesama muslim, maka tugas yang harus dilakukan adalah menolong sesama, bisa melalui kerja sama dalam perekonomian, atau pendistribusian kekayaan melalui zakat, infaq, sedekah dan sejenisnya.

\section{KESIMPULAN}

Berdasarkan pembahasan di atas, penulis menyimpulkan dalam 2 (dua) hal penting, yaitu pertama, keadilan dalam bidang ekonomi adalah suatu keadaan atau situasi di mana setiap orang memperoleh apa yang menjadi haknya. Berarti juga perlakuan yang adil bagi setiap orang untuk mendapatkan penghidupan yang layak sesuai dengan kebutuhan dan potensi yang ada. Keadilan ekonomi dalam syariah berarti keseimbangan antara hak dan kewajiban, dan kewajiban yang harus dipenuhi oleh manusia dengan kemampuan manusia untuk menunaikan kewajiban itu. Dalam Islam, penegak keadilan pada hakikatnya adalah Allah Swt., di mana keadilan akan tercipta dengan mengikuti aturan-aturan sebagaimana diajarkan dalam Al-Qur'an dan Al-Sunnah. Dalam arti lain keadilan tercipta dengan mengikuti aturan sesuai dengan asas, prinsip, dan etika perekonomian dalam syariah.

Dan kedua, keberadaan sistem ekonomi syariah menyelaraskan sistem ekonomi kapitalis dan ekonomi sosialis. Bahkan sistem ekonomi syariah cenderung berdiri sendiri dan terlepas dari sistem ekonomi lainnya, di mana ekonomi syariah menerapkan asas efisiensi dan manfaat dengan tetap menjaga kelestarian alam, dan yang menjadi motifnya adalah mencari keberuntungan di dunia dan akhirat selaku khalifatullah dengan jalan beribadah dalam arti yang luas. Karenanya, ekonomi Islam dianggap bahkan menjadi sistem ekonomi alternatif yang mampu meningkatkan kesejahteraan umat. 
DAFTAR PUSTAKA

Al-'Assal, Ahmad Muhammad dan Fathi Ahmad Abdul Karim. Sistem Ekonomi Islam: Prinsip-prinsip dan Tujuantujuannya. Surabaya: PT. Bina Ilmu, 1980.

Al-Arif, M. Nur Rianto. Lembaga Keuangan Syariah: Suatu Kajian Teoretis Praktis. Bandung: CV Pustaka Setia, 2012.

Ali, Zainuddin. Hukum Ekonomi Syariah. Jakarta: Sinar Grafika, 2008.

Anshori, Abdul Ghofur. Aspek Hukum Reksa Dana Syariah di Indonesia. Bandung: Refika Aditama, 2008.

Fatoni, Siti Nur. Pengantar Ilmu Ekonomi. Bandung: Pustaka Setia, 2014.

Harahap, Sofyan Safri. "Peluang Ekonomi Syariah dalam Otonomi Daerah", Ekonomi Syariah. Vol. 4, No. 8 (Juni, 2006).

Mannan, M. Abdul. Ekonomi Syariah: Dari Teori ke Praktek, terj. Potan Arif Harahap. Jakarta: PT. Intermasa, 1992.

Mardani. Hukum Ekonomi Syariah di Indonesia. Bandung: PT. Refika Aditama, 2011.

Naqvi, Syed Nawab Heider. Islam, Economics, and Society. London and New York: Kegan Paul International, 1994.

Praja, Juhaya S. Filsafat Hukum Antar Mazhab-Mazhab Barat dan Islam. Bandung: Latifah Press dan Yayasan Prof. Dr. Juhaya Setyapradja Center, 2014.

Qardhawi, Yusuf. Norma dan Etika Ekonomi Islam, terj. Zainal Arifin. Jakarta: Gema Insani Press, 1995.

Rivai, Veithzal dan Andi Buchari. Islamic Economics. Jakarta: Bima aksara, 2009.

Samuelson, Paul A. dan William D. Nordhaus. Ekonomi, Jilid 1, terj. Jaka Wasana. Jakarta: Erlangga, 1990.

Sastradipoera, Komaruddin. Sejarah Pemikiran Ekonomi: Suatu Pengantar Teori dan Kebijaksanaan Ekonomi. Bandung: Kappa-Sigma, 2001.
Shihab, M. Quraisy. Wawasan Al-Qur'an. Bandung: Mizan, 1996.

Siddiqi, Mohammad Nejatullah. Role of the State in the Economy: An Islamic Perspective. UK: The Islamic Foundation, 1992.

Zaman, S. M. Hasanuz. Economic Functions of an Islamic State. London: The Islamic Foundation, 1991. 